\title{
Deteksi Aktivitas Fibrinolitik Isolat Bakteri WU 021055* Asal Perairan Pantai Papuma Jember Menggunakan Zimografi
}

\author{
Evi Umayah Ulfa, ${ }^{1}$ Esti Utarti, ${ }^{2}$ Izzay Afkarina, ${ }^{2}$ Sattya Arimurti, ${ }^{2}$ Kartika Senjarini ${ }^{2}$ \\ ${ }^{1}$ Fakultas Farmasi, Universitas Jember, Jember, \\ ${ }^{2}$ Jurusan Biologi, Fakultas Matematika dan Ilmu Pengetahuan Alam, Universitas Jember, Jember
}

\begin{abstract}
Abstrak
Bakteri merupakan sumber penting berbagai enzim termasuk enzim fibrinolitik. Enzim ini diperlukan untuk mendegradasi bekuan darah pada orang yang mengalami penyakit trombosis. Isolat bakteri WU $021055^{*}$ asal Pantai Papuma Jember terbukti menghasilkan enzim fibrinolitik ekstraseluler. Penelitian ini bertujuan mengetahui ukuran protein yang memiliki aktivitas fibrinolitik dan mengidentifikasi karakteristik morfologi isolat WU bakteri WU 021055*. Penelitian ini dilakukan di Laboratorium Mikrobiologi, Fakultas Matematika dan Ilmu Pengetahuan Alam, Universitas Jember pada April-Agustus 2014. Aktivitas fibrinolitik presipitat protein (PP) ditentukan menggunakan metode fibrin plate agar dan zimografi fibrin. Ekstrak protein kasar (EPK) dipanen pada jam ke-12 dan dipresipitasi menggunakan amonium sulfat $80 \%$. Hasil uji aktivitas fibrinolitik menggunakan fibrin plate agar menunjukkan presipitat memiliki aktivitas fibrinolitik lebih besar dibanding dengan EPK. Dari hasil karakterisasi PP menggunakan sodium dodecyl sulphate polyacrylamide gel electrophoresis (SDS-PAGE) diperoleh 11 pita protein dengan ukuran 12-41 kDa. Berdasar atas hasil zimografi fibrin, pita protein dengan berat molekul $24 \mathrm{kDa}$ yang memberikan aktivitas fibrinolitik. Protein dengan ukuran $24 \mathrm{kDa}$ ini mampu mendegradasi substrat fibrin. Simpulan, isolat bakteri WU $021055^{*}$ mengandung berbagai protein ekstraseluler, memiliki bentuk koloni bulat berwarna putih dan termasuk bakteri gram prositif berbentuk batang.
\end{abstract}

Kata kunci: Bakteri WU 021055*, fibrinolitik, isolat, zimografi

\section{Detection of Fibrinolytic Activity of WU $021055^{*}$ Bacterial Isolate from Papuma Beach Coastal Jember Using Zymography}

\begin{abstract}
Bacteria were important resources for various enzymes including fibrinolytic enzymes. This enzyme is capable of degrading fibrin clot in patient with thrombotic diseases. Bacterial isolate of WU 021055* from Papuma Beach Coastal Jember could secrete extracellular fibrinolytic enzymes. The objective of this reasearch was to determine the molecular weight of protein responsible for fibrinolytic activity and to identify morphologycal characterization of bacterial isolate of WU $021055^{*}$. This study was conducted at Laboratory of Microbiology, Faculty of Mathematics and Natural Sciences, Universitas Jember in April-August 2014. Fibrinolytic activity of precipitate protein (PP) was determined by using fibrin plate agar and fibrin zymography. Crude protein extract (CPE) was harvested at 12 hours and precipitated by $80 \%$ ammonium sulphates. The result of fibrinolityc activity determination showed that fibrinolytic activity of PP was higher than CPE. Protein characterization of PP by using sodium dodecyl sulphate polyacrylamide gel electrophoresis (SDS-PAGE) obtained 11 different protein bands corresponds to value 12-42 $\mathrm{kDa}$. Based on fibrin zymography, the $24 \mathrm{kDa}$ protein might contribute to fibrinolytic activity due to degraded fibrin substrates. In conclusion, bacterial isolate of WU 021055* contained extracellular fibrin protein was white colony and gram positives bacilli able to degraded.
\end{abstract}

Key words: Fibrinolytic, isolates, WU $021055^{*}$ bacteria, zymography

Korespondensi: Evi Umayah Ulfa. Bagian Biologi Farmasi, Fakultas Farmasi, Universitas Jember. Jln. Kalimantan I/2, Jember, Jawa Timur, Indonesia. Telepon: +62331 324736. E-mail: evi.farmasi@unej.ac.id 


\section{Pendahuluan}

Fibrin merupakan komponen yang utama proses pembentukan sumbat trombosit pada saat luka. Fibrin dibentuk dari fibrinogen dan trombin (EC 3.4.21.5). Pada sistem homeostasis normal, setelah terbentuk sumbat trombosit, terdapat regulasi untuk mencegah pembentukan bekuan darah yang berlebihan. Salah satu mekanisme kontrol tersebut, yaitu aktivasi fibrinolisis dengan mempergunakan plasmin (EC 3.4.21.7) untuk menghancurkan bekuan darah. ${ }^{1}$

Abnormalitas sistem homeostasis tersebut akan mengakibatkan pembentukan bekuan darah berlebihan dan akan memicu berbagai penyakit yang mematikan seperti infark miokardium akut, strok iskemik, emboli paru, dan trombosis vena. ${ }^{1}$ Infark miokardium akut atau yang lebih dikenal dengan serangan jantung terjadi akibat sumbatan bekuan darah pada pembuluh darah koroner. Sumbatan terjadi diakibatkan penimbunan lipid terus menerus pada pembuluh arteri menuju jantung. ${ }^{2}$

Terapi pada penderita trombosis di antaranya operasi yang bertujuan menghilangkan sumbatan atau dengan obat-obat trombolitik yang bekerja mendegradasi gumpalan darah. ${ }^{3}$ Secara umum obat trombolitik dibagi menjadi dua golongan, yaitu fibrinolitik atau enzim mirip plasmin dan aktivator plasminogen. Aktivator plasminogen itu bekerja dengan cara mengaktifkan plasminogen untuk menjadi plasmin. Plasmin yang terbentuk inilah yang akan mendegradasi bekuan darah (fibrin). Berbeda dengan aktivator plasminogen, fibrinolitik mendegradasi bekuan darah secara langsung. ${ }^{4}$

Enzim fibrinolitik tersebut banyak dihasilkan oleh hewan, tanaman, dan juga mikroorganisme. Mikroorganisme yang berpotensi menghasilkan enzim fibrinolitik, misal bakteri, actinomycetes, dan fungi. ${ }^{5}$ Bakteri sangat berpotensi sebagai penghasil enzim yang bernilai ekonomis dengan beberapa keunggulan, antara lain pertumbuhan lebih cepat, skala produksi sel akan lebih mudah ditingkatkan, kondisi produksi tidak bergantung pada musim, waktu yang dibutuhkan relatif tidak lama, dan mudah dimanipulasi genetik. ${ }^{6}$

Luasnya daerah perairan di Indonesia (sekitar $6 \%$ sumber air dunia atau 21\% dari total sumber air di area Asia Pasifik) dan biodiversitas bakteri yang tinggi itu merupakan potensi sumber daya alam yang sangat vital untuk dimanfaatkan bagi kesejahteraan manusia. Bakteri perairan mampu menghasilkan berbagai senyawa serta memiliki karakteristik berbeda dibanding dengan bakteri terestrial disebabkan oleh kondisi lingkungan berbeda. ${ }^{7}$ Upaya mendapatkan enzim fibrinolitik asal perairan ini menarik untuk diteliti. Berbagai jenis bakteri perairan yang mampu menghasilkan enzim fibrinolitik dan telah dikarakterisasi di antaranya Bacillus subtilis A26, B. subtilis ICTF1, dan B. subtilis HQS-3. ${ }^{8-10}$

Hasil penelitian yang dilakukan sebelumnya menunjukkan isolat asal perairan Pantai Papuma WU 021055* telah terbukti mampu menghasilkan enzim fibrinolitik secara ekstraseluler. Enzim yang dihasilkan mampu mendegradasi substrat fibrin. Pada penelitian ini dilakukan uji aktivitas fibrinolitik ekstrak protein kasar dan presipitat protein bakteri WU 021055* memakai metode fibrin plate assay dan zimografi.

Zimografi merupakan salah satu metode yang mudah dan cepat mengetahui aktivitas spesifik suatu enzim melalui penambahan substrat pada gel elektroforesis. Enzim yang telah dipisahkan sesuai ukurannya dengan elektroforesis akan mendegradasi substrat yang telah ditambahkan pada gel.

\section{Metode}

Bahan yang dipergunakan adalah isolat bakteri WU 021055* dari perairan Pantai Papuma Jember koleksi dari Laboratorium Mikrobiologi, Jurusan Biologi dari Fakultas Matematika dan Ilmu Pengetahuan Alam, Universitas Jember, media nutrient agar (NA), media Luria Bertani broth (LB), trombin, fibrinogen, bahan untuk presipitasi protein (amonium sulfat; membran dialisis; barium klorida; dan bufer fosfat), bahan untuk sodium dodecyl sulphate polyacrylamide gel electrophoresis atau SDS-PAGE \{akrilamid 30\%; bufer Tris $\mathrm{HCl} \mathrm{pH} \mathrm{8,8;} \mathrm{bufer} \mathrm{Tris} \mathrm{HCl} \mathrm{pH}$ 6,8; amonium persulfat atau APS 10\%; sodium dodecyl sulphate atau SDS 10\%; dan N,N,N',N'tetrametiletilena diamin atau TEMED\}, marka protein HNW prestained, phosphate buffer saline atau PBS o,05 M dengan $\mathrm{pH} 7,4$, bufer elektrode, Tween 20 2,5\%, larutan pewarna (staining), dan larutan peluntur (destaining).

Alat-alat yang dipergunakan dalam penelitian ini berbagai alat gelas, neraca analitik, vorteks, inkubator, inkubator goyang, mikroskop merek Olympus BX53F, mikroskop Olympus CX21, dan seperangkat alat SDS-PAGE.

Profil pertumbuhan bakteri diawali dengan membuat kurva hubungan antara jumlah bakteri dan waktu (dalam jam) selama 24jam. Satu koloni 
tunggal bakteri dari media NA dibuat inokulum dengan cara menumbuhkannya pada media LB cair 12 jam, suhu ruang dengan penggoyangan. Sebanyak $500 \mu \mathrm{L}$ inokulum bakteri ditumbuhkan pada $50 \mathrm{~mL}$ media LB cair dan disampling setiap 2 jam dengan cara $900 \mu \mathrm{L}$ kultur diambil dan dimasukkan ke dalam tabung mikrosentrifugal $1,5 \mathrm{~mL}$ yang sudah berisi $100 \mu \mathrm{L}$ formaldehida. Jumlah bakteri dihitung di bawah mikroskop Olympus CX21 menggunakan haemocytometer sampai jam ke-26.

Pembuatan kurva pertumbuhan bakteri itu ditentukan berdasar atas Lengeler dkk. ${ }^{11}$ dengan rumus sebagai berikut:

$$
\begin{aligned}
& \mu=\frac{\lg \mathrm{N}_{\mathrm{t}}-\mathrm{N}_{\mathrm{o}}}{\lg \mathrm{e}\left(\mathrm{t}-\mathrm{t}_{\mathrm{o}}\right)}=\frac{\ln \mathrm{N}_{\mathrm{t}}-\ln \mathrm{N}_{\mathrm{o}}}{\mathrm{t}-\mathrm{t}_{\mathrm{o}}} \\
& \qquad \mathrm{N}_{\mathrm{t}}=\mathrm{N}_{\mathrm{o}} \times \mathrm{e}^{\mu \times \mathrm{t}} \\
& \mathrm{t}=\text { waktu ke- } \mathrm{t} \\
& \mu=\text { kecepatan pertumbuhan } \\
& \mathrm{t}_{\mathrm{o}}=\text { waktu ke-o } \\
& \mathrm{N}_{\mathrm{o}}=\text { jumlah sel pada waktu } \mathrm{t}_{\mathrm{o}} \\
& \mathrm{N}_{\mathrm{t}}=\text { jumlah sel pada waktu ke- } \mathrm{t}
\end{aligned}
$$

Data yang diperoleh digunakan untuk membuat kurva sigmoid memakai aplikasi SOLVER pada program Microsoft Excel 2007. ${ }^{12}$

Produksi enzim ekstraseluler dilaksanakan dengan starter inokulum isolat bakteri sebanyak $10 \mathrm{~mL}$ starter (2\% (v/v)) pada $500 \mathrm{~mL}$ media LB cair dan diinkubasi goyang 130 rpm selama 12 jam (kisaran fase eksponensial) pada suhu ruang. Kultur dipanen dengan sentrifugasi $10.000 \mathrm{rpm}$ pada suhu $4^{\circ} \mathrm{C}$ selama 15 menit. Supernatan yang diperoleh merupakan ekstrak protein kasar (EPK).

Ekstrak protein kasar (EPK) yang diperoleh dipresipitasi dengan penambahan $\left(\mathrm{NH}_{4}\right)_{2} \mathrm{SO}_{4}$ jenuh $80 \%$ sesuai tabel ${ }^{13}$ sedikit demi sedikit dengan pengadukan $150 \mathrm{rpm}$ mempergunakan magnetic stirrer pada suhu dingin selama 60 menit. Endapan disentrifugasi 10.000 rpm pada suhu $4^{\circ} \mathrm{C}$ selama 10 menit. Pelet yang diperoleh dikeringkan dengan pengeringan beku (freeze drying) dan dilarutkan ke dalam PBS pH 7,4 dengan perbandingan 1:2(b/v). Larutan presipitat didialisis untuk menghilangkan amonium sulfat selama 36 jam dengan penggantian bufer 0,05 M PBS pH 7,4 setiap 12 jam. Dialisat yang diperoleh disebut presipitat protein (PP).

Ekstrak protein kasar (EPK) dan PP yang diperoleh lalu diuji aktivitas fibrinolitiknya secara semikuantitatif mempergunakan metode fibrin plate assay. ${ }^{14}$ Media agar fibrin dibuat dengan cara mencampurkan $100 \mu \mathrm{L}$ trombin dalam $0,5 \mathrm{M}$ $\mathrm{CaCl}_{2}$ dengan $4 \mathrm{~mL}$ agarosa cair steril yang sudah mengandung $900 \mu \mathrm{L}$ fibrinogen $0,1 \%$ dalam PBS $\mathrm{pH} 7,4$. Setelah memadat, sampel sebanyak $10 \mu \mathrm{L}$ diteteskan pada membran cakram diameter 0,55 $\mathrm{cm}$ dan diinkubasi pada suhu $37^{\circ} \mathrm{C}$ selama 24 jam. Keberhasilan pengujian ditunjukkan dengan terbentuknya zona bening di sekitar membran.

Profil protein PP isolat bakteri WU 021055* ditentukan memakai SDS-PAGE 12,5\% dengan pewarna yang dipakai adalah coomasive blue. Terdapat protein tersebut diperlihatkan dengan munculnya pita protein. Berat molekul protein yang memiliki aktivitas fibrinolitik ditentukan memakai metode zimografi dengan penambahan substrat fibrin pada gel.

Sebanyak $1 \mathrm{~mL}$ fibrinogen $0,25 \%$ dan 0,2 $\mathrm{mL}$ trombin $0,1 \%$ ditambahkan pada $10 \mathrm{~mL}$ separating gel. Sampel presipitat protein atau PP sebanyak $10 \mu \mathrm{L}$ ditambah dengan $10 \mu \mathrm{L}$ bufer sampel tanpa $\beta$-merkaptoetanol dan pemanasan. Gel zimografi diamati menggunakan coomasive blue stain setelah direnaturasi dalam 2,5\% Tween 20 (v/v) dengan penggoyangan selama 1 jam dan didigesti menggunakan $0,05 \mathrm{M}$ bufer fosfat $\mathrm{pH} 8$ pada suhu $60^{\circ} \mathrm{C}$ selama 30 menit. Zona bening yang terbentuk akan menunjukkan protein yang memiliki aktivitas fibrinolitik. Berat molekul protein itu ditentukan melalui ekstrapolasi pada garis regresi antara log BM dan jarak migrasi marka protein HMW.

Morfologi isolat tersebut ditentukan melalui pengamatan secara langsung koloni tunggal WU 021055* dan pewarnaan gram. Hasil pewarnaan diamati menggunakan mikroskop pembesaran 1.000x. Sel bakteri gram positif akan berwarna ungu hingga biru, sedangkan bakteri gram negatif akan berwarna merah.

Penelitian ini telah memperoleh persetujuan dari Komisi Etik Penelitian, Fakultas Kedokteran, Universitas Jember, dengan No. 1.178/H25.1.11/ $\mathrm{KE} / 2017$.

\section{Hasil}

Profil kurva pertumbuhan isolat bakteri WU 021055*asal Pantai PapumaJemberdiperlihatkan pada Gambar 1. Kurva pertumbuhan isolat bakteri itu berbentuk sigmoid dengan 3 fase, yaitu fase adaptasi, fase eksponensial, dan fase stasioner. Hasil pengujian aktivitas fibrinolitik EPK dan PP menggunakan media agar fibrin dapat dilihat pada Gambar 2.

Hasil SDS-PAGE dan zimografi PP isolat 


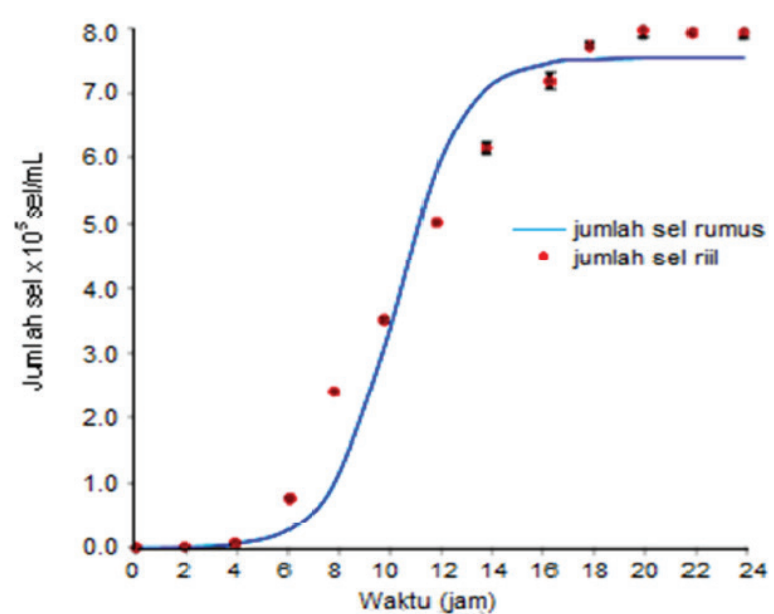

\section{Gambar 1 Kurva Pertumbuhan Isolat Bakteri WU 021055* dari Perairan Pantai Papuma Jember Selama 24 Jam}

bakteri WU 021055* dapat dilihat pada Gambar 3. Hasil SDS-PAGE dan zimografi menunjukkan pita protein pada PP isolat bakteri WU 021055* yang memberikan daerah bening.

Morfologi bakteri dan pewarnaan gram isolat bakteri WU 021055* dapat dilihat pada Gambar 4. Koloni bakteri di media dan hasil pewarnaan gram diamati di bawah mikroskop.

\section{Pembahasan}

Hasil dari pembuatan profil kurva pertumbuhan (Gambar 1) memperlihatkan fase eksponensial

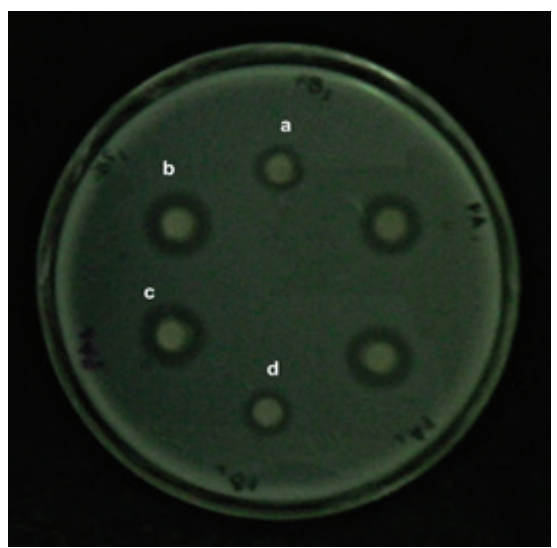

Gambar 2 Aktivitas Fibrinolitik EPK dan PP Isolat Bakteri WU 021055* Secara Semikuantitatif pada Media Fibrin Agar. a, d: EPK; b, c: PP
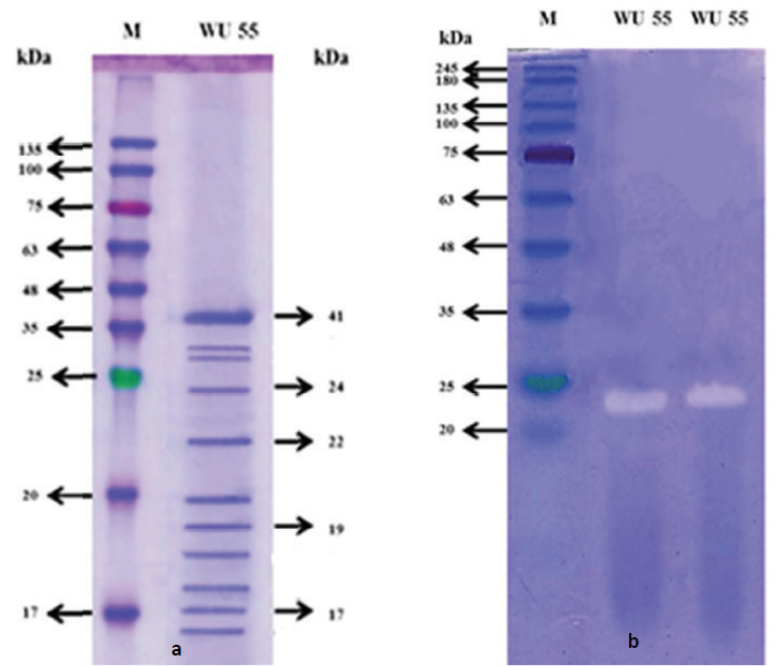

Gambar 3 Elektroforegram dan Zimografi Dialisat Isolat Bakteri WU 021055* dari Perairan Pantai Papuma Jember. a. SDS-PAGE, b. hasil zimografi. Daerah bening menunjukkan aktivitas fibrinolitik. M: marka protein HMW; WU 55: PP

isolat bakteri WU 021055* dimulai pada jam ke-8 sampai jam ke-20. Fase adaptasi terjadi sebelum jam ke-8, sedangkan fase stasioner setelah jam ke-20. Fase adaptasi berlangsung selama satu jam hingga beberapa jam bergantung pada jenis bakteri, umur biakan, dan nutrien yang terdapat dalam media.

Setelah sel bakteri tersebut mengalami fase pertumbuhan awal maka sel bakteri memasuki fase eksponensial. Pada fase eksponensial ini sel mulai membelah dengan kecepatan yang sangat cepat. Kebutuhan akan energi bagi bakteri pada fase ini lebih tinggi dibanding dengan fase lainnya dan pada fase ini sel banyak menghasilkan enzim

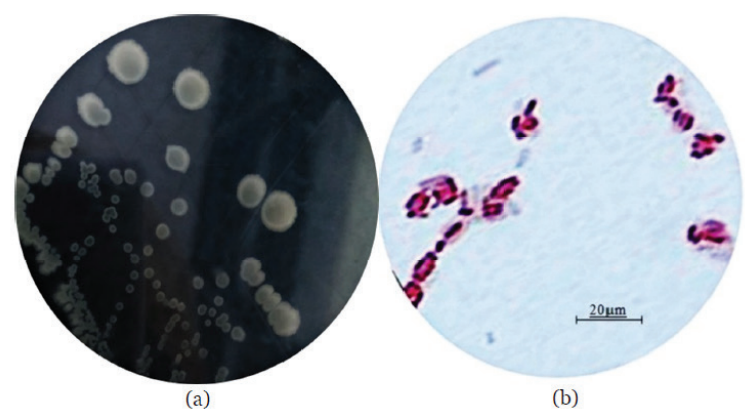

Gambar 4 Morfologi Isolat Bakteri WU 021055*. (a) bentuk koloni, (b) pewarnaan gram 
dan zat-zat metabolit primer untuk memenuhi kebutuhan pertumbuhan dan perkembangannya. Pertumbuhan bakteri yang sangat cepat pada fase eksponensial menunjukkan bahwa pada fase tersebut bakteri memiliki aktivitas yang tinggi dan metabolisme yang terbaik. ${ }^{11}$

Berdasar atas kurva pertumbuhan itu maka produksi enzim ekstraseluler isolat WU 021055* dilakukan pada jam ke-12, yaitu saat bakteri telah mendekati puncak fase eksponensial. Aktivitas metabolisme bakteri pada fase tersebut sudah mencapai puncak sehingga enzim yang dihasilkan juga maksimal.

Aktivitas fibrinolitik EPK dan PP ditentukan dengan cara/metode cawan, yaitu menggunakan campuran fibrinogen bersama dengan trombin yang dilarutkan dalam media agar. Metode ini sangat spesifik untuk mengetahui kemampuan enzim dalam mendegradasi fibrin. Fibrinogen dan trombin yang dilarutkan ke dalam media agarosa akan saling berinteraksi dan membentuk bekuan fibrin yang berfungsi sebagai substrat enzim.

Hidrolisis bekuan fibrin dipergunakan untuk dapat menunjukkan aktivitas hidrolitik enzim fibrinolitik. Enzim akan mengkatalisis degradasi bekuan fibrin, yaitu dengan memutuskan ikatan fibrinopeptida menghasilkan produk degradasi fibrin seperti D-mer asam amino.

Hasil pengujian aktivitas fibrinolitik (Gambar 2) menunjukkan aktivitas fibrinolitik EPK dan PP secara berturut-turut adalah 0,65 $\pm 0,006$ dan 1,45 $\pm 0,006 \mathrm{~mm}$. Aktivitas fibrinolitik PP lebih tinggi dibanding dengan EPK karena jumlah enzim yang terkandung lebih banyak. PP protein ini selanjutnya di SDS-PAGE dan zimografi untuk mengetahui ukuran enzim yang memberikan aktivitas fibrinolitik.

Berdasarkan atas hasil SDS-PAGE (Gambar 3a), PP isolat bakteri WU $021055^{*}$ memiliki 13 pita protein dengan ukuran mulai dari $12 \mathrm{kDa}$ hingga $41 \mathrm{kDa}$. Jumlah pita yang cukup banyak menunjukkan beragamnya kandungan protein pada isolat bakteri WU $021055^{*}$.

Zimografi pada penelitian ini menggunakan gel poliakrilamid 12,5\% yang diimpregnasi dengan fibrin. Gel hasil elektroforesis direnaturasi dengan tween untuk mengembalikan konformasi protein yang berubah saat elektroforesis dan digesti agar protein isolat WU $021055^{*}$ mendegradasi substrat fibrin yang terdapat pada gel.

Hasil zimografi menunjukkan protein dengan berat molekul $\sim 24 \mathrm{kDa}$ mempunyai aktivitas fibrinolitik (Gambar 3b). Aktivitas fibrinolitik ditunjukkan dengan terbentuknya zona bening hasil pemecahan substrat fibrin oleh protein tersebut. Berat molekul enzim ini mirip dengan enzim fibrinolitik yang dihasilkan oleh $B$. substilis BA $9920(30 \mathrm{kDa})^{15}$ dan $B$. licheniformis strain KJ-31 menghasilkan berat molekul $37 \mathrm{kDa} .^{16}$

Pada pengamatan morfologi koloni isolat bakteri diperoleh hasil bahwa koloni isolat bakteri WU 021055* berbentuk bulat putih dengan tepi bergerigi. Hasil pewarnaan gram didapatkan bahwa isolat bakteri WU 021055* itu termasuk bakteri gram positif berbentuk basil (Gambar 4). Bakteri perairan berbentuk basil gram positif yang mampu menghasilkan enzim fibrinolitik di antaranya $B$. circulans $^{17}$ yang menghasilkan enzim fibrinolitik dengan ukuran $24-36 \mathrm{kDa}$, B. subtilis A268 dan B. subtilis HQS-3 dengan ukuran enzim $26 \mathrm{kDa}^{10}$

\section{Simpulan}

Berdasar atas hasil penelitian dapat disimpulkan isolat bakteri WU 021055* mengandung berbagai protein ekstraseluler. Protein dengan ukuran 24 kDa mampu mendegradasi substrat fibrin. Isolat bakteri WU 021055* merupakan bakteri gram positif berbentuk batang.

\section{Ucapan Terima Kasih}

Terima kasih diucapkan kepada DIPA Universitas Jember yang telah membiayai penelitian ini melalui program penelitian Fundamental 2014.

\section{Daftar Pustaka}

1. Ali MR, Salim Hossain M, Islam MA, Saiful Islam Arman M, Sarwar Raju G, Dasgupta P, dkk. Aspect of thrombolytic therapy: a review. Sci World J. 2014;2014:586510.

2. Kania A, Kharisma Y, Dewi MK. Bekatul (Oryza sativa L) menghambat peningkatan kadar kolesterol darah. GMHC. 2014;2(1):3441.

3. Kunamneni A, Abdelghani TTA, Ellaiah P. Streptokinase-the drug of choice for thrombolytic therapy. $\mathrm{J}$ Thromb Thrombolysis. 2007;23(1):9-23.

4. Choi BS, Sapkota K, Choi JH, Shin CH, Kim S, Kim SJ. Herinase: a novel bi-functional fibrinolytic protease from the monkey head mushroom, Hericium erinaceum. Appl Biochem Biotechnol. 2013;170(3):609-22.

5. Kotb E. Fibrinolytic bacterial enzymes 
with thrombolytic activity. Berlin: Springer Heidelberg; 2012.

6. Ningthoujam DS, Thokchom S. Screening of fibrinolytic enzymes from microorganisms especially actinomycetes from different biotopes in Manipur. Arch Clin Microbiol. 2016;7(3):21.

7. Vignesh S, Raja A, James RA. Marine drugs: implication and future studies. Int $\mathrm{J}$ Pharmacol. 2011;7(1):22-30.

8. Agrebi R, Haddar A, Hmidet N, Jellouli K, Manni L, Nasri M. BSF1 fibrinolytic enzyme from a marine bacterium Bacillus subtilis A26: Purification, biochemical and molecular characterization. Process Biochem. 2009;44(11):1252-9.

9. Mahajan PM, Nayak S, Lele SS. Fibrinolytic enzyme from newly isolated marine bacterium Bacillus subtilis ICTF-1: media optimization, purification and characterization. $\mathrm{J}$ Biosci Bioeng. 2012;113(3):307-14.

10. Huang S, Pan S, Chen G, Huang S, Zhang Z, $\mathrm{Li}$ Y, dkk. Biochemical characteristics of a fibrinolytic enzyme purified from a marine bacterium, Bacillus subtilis HQS-3. Int J Biol Macromol. 2013;62:124-30.

11. Lengeler JW, Drews G, Schlegel HG, penyunting. Biology of prokaryotes. Hoboken, New Jersey: Wiley-Blackwell; 2009.

12. Arifin J, Utami FV. Eksplorasi Microsoft
Excel untuk simulasi bisnis. Jakarta: PT Elex Media Komputindo; 2012.

13. Doung-Li KC, Gabelli SB. Salting out of proteins using ammonium sulfate precipitation. Methods Enzymol. 2014;541: 85-94.

14. Zhao M. Methods and applications of thrombus-related assay. Dalam: Peng S, Zhao $M$, penyunting. Pharmaceutical bioassays: methods and applications. Hoboken, New Jersey: John Willey and Son Inc; 2009. hlm. 45-64.

15. Chen B, Hou J, He Z, He Q, Hao Y, Chen Z. Isolation and identification of an effective fibrinolytic strain Bacillus subtilis FR-33 from the Chinese doufuru and primary analysis of its fibrinolytic enzyme. Afr J Microbiol Res. 2013;7(19):2001-9.

16. Hwang KJ, Choi KH, Kim MJ, Park CS, Cha J. Purification and characterization of a new fibrinolytic enzyme of Bacillus licheniformis KJ-31, isolated from Korean traditional Jeotgal. J Microbiol Biotechnol. 2007;17(9): 1469-76.

17. Sadeesh Kumar R, Rajesh R, Gokularishnan $S$, Subramanian J. Screening and characterization of fibrinolytic protease producing Bacillus circulans from mangrove sediments Pitchavaram, South East Coast of India. Int Lett Nat Sci. 2015;28:10-6. 